\title{
DEVELOPMENT OF MEDICAL NOMENCLATURE AND ALGORITHMS FOR DIAGNOSIS AND TREATMENT OF GOUT IN OUTPATIENT SETTINGS
}

\author{
Osmolovsky IS $\bowtie$, Zarubina TV, Shostak NA, Kondrashov AA, Klimenko AA
}

Pirogov Russian National Research Medical University, Moscow, Russia

\begin{abstract}
Gout is a chronic systemic disease characterized by the deposition of monosodium urate crystals in various tissues and inflammation. In Russia, time to diagnosis may be as long as 8 years. This leads to serious complications, such as urate nephropathy, and disability. Effective strategies are needed to improve the quality of medical care for gout patients. One of such strategies is creation of an expert system to aid the clinician in establishing the diagnosis and selecting adequate therapy. The cornerstone of an expert system is a knowledge base. The aim of this paper was to develop a medical nomenclature and algorithms for the diagnosis and treatment of gout that will be used to create an expert system in the future. A total of 1,174 entities were selected that laid the basis for 40 diagnostic and 50 treatment algorithms for gout patients. All informational models were verified by the expert panel.
\end{abstract}

Keywords: ontology, knowledge base, expert system, CDSS, clinical decision support system, gout

Author contribution: Osmolovsky IS built and performed technical verification of the medical nomenclature and algorithms for the diagnosis and treatment of gout, analyzed information provided by the expert panel, wrote the technical section of the paper and prepared figures and tables; Zarubina TV proposed the design of the study, supervised the study, analyzed information provided by the expert panel and performed technical verification of the informational objects; Shostak NA Kondrashov AA, Klimenko AA collected data for the informational objects, performed clinical verification of the informational objects and wrote the clinical section of this paper.

Compliance with ethical standards: the study was approved by the Ethics Committee of Pirogov Russian National Research Medical University (Protocol № 192 dated January 27, 2020).

$\triangle$ Correspondence should be addressed: Ivan S. Osmolovsky Ostrovityanova, 1, Moscow, 117997; osmolovsky_ivan@bk.ru

Received: 03.03.2021 Accepted: 01.04.2021 Published online: 17.04.2021

DOI: 10.24075/brsmu.2021.014

\section{РАЗРАБОТКА НОМЕНКЛАТУРЫ ПОНЯТИЙ И ЛОГИЧЕСКИХ СХЕМ ПО АМБУЛАТОРНОМУ ВЕДЕНИЮ ПАЦИЕНТОВ С ПОДАГРОЙ}

И. С. Осмоловский $\bowtie$, Т. В. Зарубина, Н. А. Шостак, А. А. Кондрашов, А. А. Клименко

Российский научно-исследовательский медицинский университет имени Н. И. Пирогова, Москва, Россия

\begin{abstract}
Подагра является системным тофусным заболеванием, для которого характерны отложение в различных тканях кристаллов моноурата натрия и развивающееся в связи с этим воспаление. Диагностика подагры в среднем по России длится до 8 лет. Этого времени достаточно для развития различных осложнений (например, подагрической нефропатии) и инвалидизации пациента. Необходимы стратегии улучшения качества оказываемой помощи пациентам. К одной из таких стратегий можно отнести создание экспертной системы, которая могла бы помочь специалистам заподозрить подагру и рекомендовать тактику ее лечения. Основой экспертной системы является база знаний. Целью исследования было сформировать номенклатуру медицинских понятий и логических схем ведения пациентов при диагностике и лечении подагры для разработки экспертной системы. В ходе разработки номенклатуры было собрано 1174 понятия, которые легли в основу 40 логических схем по диагностике подагры и 50 логических схем лечения заболевания. Все указанные информационные модели верифицированы экспертами.
\end{abstract}

Ключевые слова: онтология, база знаний, экспертная система, система поддержки принятия врачебных решений, подагра

Вклад авторов: И. С. Осмоловский - формирование и техническая верификация информационных объектов (номенклатуры медицинских понятий и логических схем диагностики и лечения подагры), анализ предоставленной экспертами информации, написание техническои части рукописи и формирование таблиц и рисунков; Т. В. Зарубина - общее руководство, дизайн исследования, подготовка рукописи, анализ предоставленной экспертами информации, техническая верификации информационных объектов; Н. А. Шостак, А. А. Клименко, А. А. Кондрашов - сбор информации для создания информационных объектов, клиническая верификация информационных объектов, написание клинической части рукописи.

Соблюдение этических стандартов: исследование одобрено этическим комитетом РНИМУ им. Н. И. Пирогова (протокол № 192 от 27 января 2020 г.).

$\triangle$ Для корреспонденции: Иван Сергеевич Осмоловский

ул. Островитянова, д. 1, г. Москва, 117997; osmolovsky_ivan@bk.ru

Статья получена: 03.03.2021 Статья принята к печати: 01.04.2021 Опубликована онлайн: 17.04.2021

DOI: 10.24075/vrgmu.2021.014

Gout is a chronic systemic disease characterized by the deposition of monosodium urate crystals (tophi) in various tissues and the ensuing inflammation in patients with hyperuricemia associated with environmental and/or genetic factors. Gout affects 1-2\% of the world's adult population [1]. According to clinical guidelines, gout can be effectively managed using a treat-to-target approach that consists in achieving and maintaining a target serum urate level. Sustained reduction in serum urate below $360 \mu \mathrm{mol} / \mathrm{L}$ results in the dissolution of monosodium urate crystals and prevents gout flares. However, delays in the initiation of urate-lowering therapy and poor adherence to treatment are common worldwide; therefore, target serum urate levels are rarely achieved, as demonstrated by laboratory tests [1]. Effective strategies are needed to improve the quality of medical care for gout patients.

In Russia, the estimated time from the first gout attack to formal diagnosis is $4-8$ years [2-5]; diagnostic delays result in severe complications and comorbidities.

The timely diagnosis of gout is constrained by a number of factors, one of them being the shortage of rheumatologists at primary healthcare and other medical facilities. According to Russian health law [6], there should be at least one rheumatologist per 30,000 population. In practice, there are 0.07 rheumatologists per 10,000 population or 0.21 rheumatologists per 30,000 population, i.e. their number is 
5 times lower than recommended $[7,8]$, hence the delays in delivering adequate medical care to gout patients.

Another problem is the lack of access to polarized light microscopy, the gold standard diagnostic test for gout [1, 9]. It is not a routine method; it cannot be used in every clinical setting and must be performed by specially trained staff [4, 9]. So, practicing physicians have little choice but to exclusively rely on clinical symptoms, which they may misinterpret during the first visit [10].

Modern technology can reduce the rate of medical errors and improve the quality of healthcare delivered to the patient. Among technological successes are diagnostic decision support systems that have been in development since the late 1960s - early 1970s [11-13]. In the past 50 years, a large pool of ready-for-use decisions has been created, many of which are still used in clinical practice. Decision support systems can be categorized in 2 groups [14]:

- systems based on machine learning: genetic algorithms, artificial neural networks, support vectors, etc. [15];

- knowledge-based systems, such as expert systems [13].

Systems that rely on machine learning (medical image processing) exploit massive databases (up to a few thousand cases) and are not required to explain the decision to the clinician have proved to be effective in many medical fields. But in the case of gout, knowledge-based systems that can operate in the absence of sufficient amount of data are more suitable. These systems are based on texts and expert knowledge and can aid the clinician in taking informed decisions $[12,13,16]$.

A knowledge base is the product of knowledge engineering that develops methods for knowledge extraction, structuring and formalization. There are a few established models of knowledge representation, including production models, frames, sematic networks, etc. [12, 13, 17]. However, the modularity, ambiguity, incompleteness, and some other characteristics of a given subject area are difficult to represent using existing models [12]. To circumvent these challenges, an ontological approach can be applied; it allows developing a hierarchical nomenclature of strictly defined medical entities [12].

An ontology is a formal specification of a shared conceptual model, i.e. an abstract model of a given subject field that explicitly describes the conceptual framework of this field, is accepted by a given community and has a formal representation [12, 13]. Conventionally, ontologies are represented by semantic networks, i.e. the entirety of linked concepts; however, there are other methods of knowledge representation, including frames and production rules.

Thus, building an ontology is one of the key stages in the development of an expert system that can provide a clinician with comprehensive information about a disease. But building a medical ontology is impossible without a nomenclature of medical entities and diagnostic/treatment algorithms [12, 13]; so far, no such information objects have been constructed.

The aim of this study was to develop formal algorithms for the diagnosis and treatment of gout in an outpatient setting that could be further used to build an expert system.

\section{METHODS}

Federal clinical guidelines approved by the Russian Ministry of Health [1] were used as the main source of data for creating a medical nomenclature and diagnostic/treatment algorithms for gout. The State Registry of Medicinal Products [18] and academic publications were used as additional sources of information.

Eligibility criteria for experts participating in the development of an expert system or a similar product are not explicitly specified in Russian normative documents, so the selection was based on the formal indicators of expertise, including academic credentials, position held, and over 8 years of experience in rheumatology. The panel of experts consisted of 3 highly skilled rheumatologists from Nesterov Department of Faculty Therapy at Pirogov Russian National Research Medical University.

Diagnostic and treatment algorithms for gout were developed using MS Excel (Microsoft; USA), MS Excel Online (Microsoft; USA) and Visio (Microsoft; USA) software.

The process of developing the nomenclature of medical entities pertaining to the diagnosis and treatment of gout included the following steps:

- entities were identified using text-based methods of knowledge extraction;

- working independently - each member of the panel made corrections to the nomenclature by modifying, adding or removing the identified entities;

- the obtained results were validated by comparison and voting.

For the comparison procedure, each expert was given a nomenclature version drawn from textual sources. The members of the expert panel revised and modified the received nomenclature independent of each other. The resultant versions were compared, and the variations were brought forward for voting so as to enrich the final version of the nomenclature with new entities.

Diagnostic algorithms were developed using 2015 ACR/ EULAR gout classification criteria. Treatment algorithms were based on the clinical guidelines proposed by the Russian Association of Rheumatologists [1, 19]. Diagnostic and treatment algorithms for gout were developed following the same steps as in the development of the medical nomenclature.

\section{RESULTS}

\section{Medical nomenclature}

Creating a nomenclature of medical entities pertaining to the diagnosis and treatment of gout was a multistep process that allowed us to identify 1,174 entities. As part of this process, we were faced with the need to formulate a number of requirements in order to keep the nomenclature from overgrowing and to get rid of some nomenclature items that were not used in decision making. Briefly, we had to

1. Identify entities related to the diagnosis and treatment of gout only. Entities not related to gout were not included in the nomenclature. For example, the entities "heartburn" or "gastric ulcer" are not used to diagnose or treat gout, so they were not included in the nomenclature.

2. Extract revised terminology. For example, the term "urate"/"uric acid" was not included in the nomenclature because it lacks accuracy: uric acid can be measured in various bodily fluids like urine, synovial fluid etc., and its reference levels used for diagnostic or monitoring purposes are different. Therefore, a more precise term should be used, i.e. "serum urate". By mapping the studied terms to the SNOMED databased, we were able to refine a number of terms.

3. Arrange synonyms into groups. The terminology that describes a specific phenomenon may differ across schools of medical thought. Varying terminology should be arranged in groups of synonyms. For example, "intermittent gout, intercritical period" can be clustered with "intercritical gout". It is important to select an entry that will be used by the expert system as the main term and to identify its synonyms that will redirect the system to the main term. Usually, the most 
Table 1. Clinical forms of gout

\begin{tabular}{|l|l|}
\hline \multicolumn{1}{|c|}{ Classification of clinical phases } & \multicolumn{1}{c|}{ Functional classification of joint damage } \\
\hline Acute gouty arthritis & Functional class I \\
\hline Intermittent gout, intercritical period & Functional class II \\
\hline Acute intermittent gout. Acute gouty arthritis & Functional class III \\
\hline Chronic tophaceous gout. Chronic gouty arthritis, intercritical period & Functional class IV \\
\hline Chronic tophaceous gout. Chronic gouty arthritis, acute period & \\
\hline
\end{tabular}

commonly used term is assumed to be the main term. All abbreviations of the term are regarded as its synonyms.

4. Extract umbrella terms to arrange revised terminology into groups. For example, "tophus" is an umbrella term for "subcutaneous tophi", "intraosseous tophi", and some other entities.

5. Medicinal drugs should be represented by their active pharmaceutical substances only; it is important to exclude trade names from the nomenclature.

6. Extract quantitative terms. For example, the entry "serum urate" should be annotated with its reference intervals.

Prior to working on the nomenclature, the expert panel enunciated a list of final diagnoses based on their clinical experience and verified literature sources [1, 19]. There were two components to the formulated diagnoses: the clinical stage of gout and the functional class of the affected joint (Table 1).

The analysis of textual sources yielded a nomenclature of 132 main terms and 77 synonyms pertaining to gout diagnosis. This list was revised by the expert panel; the final version of the "diagnostic" nomenclature encompassed 170 main terms and 470 synonyms. For gout therapy, the initial nomenclature compiled from literature sources included 324 main terms and 213 synonyms; its revised version comprised 387 main terms and 515 synonyms.

Some of the terms were present in both nomenclatures; after the nomenclatures were merged, the total number of main terms and their synonyms reached 495 and 679 , respectively.

The main terms were broken down in 8 types (Table 2). In the future, this terminology will be used for building an ontology to aid the diagnosis and treatment of gout.

\section{Diagnostic algorithms}

Based on Federal Clinical Guidelines [1, 19], diagnostic algorithms for gout were elaborated in a series of steps and revised. Diagnostic algorithms were developed for each of 20 definitions of clinical forms of gout formulated by the expert panel. A total of 40 scenarios were proposed (Table 3) and 52 synonyms were used.

Table 2. Types of entities used in the proposed medical nomenclature
The refined definitions of clinical forms of gout are variants of the final diagnosis that are based on various combinations of the clinical stage of gout and the functional classification of the affected joint $[19,20]$ (see Table 1). From the diagnostic perspective, both components can be regarded as independent entities. The algorithm for classifying the functional state of the affected joint is fully consistent with the Federal Clinical Guidelines [19].

The algorithm for identifying the clinical stage of gout was based on the 2015 ACR/EULAR international classification criteria [1]. The algorithm consists of 3 steps. The first step is essentially the recognition of acute gout, which involves the analysis of symptoms indicative of inflammation in the ankle, first metatarsophalangeal and mid-foot joints. While refining and revising the nomenclature, the panel expanded the list of symptoms to include knee joint inflammation and peripheral joint inflammation, which refers to the inflammation of 59-61 joints that are at lower risk for being affected by gout. Each feature (symptom) contributes to the final diagnosis and is assigned points. The threshold score for diagnosing gout is $\geq 8$ points on the ACR/EULAR scale. However, the following criteria must be taken in account when using the ACR/EULAR classification:

\section{Time-course of the disease}

Some features contribute to the diagnosis when used in combination with other features. For example, "time to maximal pain during the attack" $<24 \mathrm{~h}$ and "duration of gouty arthritis attack" of 10-14 days jointly score 1 point. The co-occurrence of these symptoms with the feature called "complete resolution of gouty arthritis symptoms" (in 10-14 days) does not affect the total score. Here, an individual feature is not assigned any points. No less significant is the combination of temporal characteristics of the disease with recurrent typical episodes: it increases the total score by 2 points.

\section{Serum urate levels}

"Serum urate" can score from -2 to 4 points, depending on its actual concentration in the blood serum. Negative values

\begin{tabular}{|c|l|c|}
\hline № & \multicolumn{1}{|c|}{ Type } & Description \\
\hline 1 & Symptom & $\begin{array}{r}\text { Disease elements identified by the clinician by means of various tests. Examples: swelling of the } \\
\text { first metatarsophalangeal joint, serum urate level }\end{array}$ \\
\hline 2 & Diagnosis & Clinical diagnosis. Example: acute gouty arthritis \\
\hline 3 & Study method & Methods for studying disease elements \\
\hline 3.1 & Instrumental method & Physical assessment techniques (palpation, percussion, auscultation) and medical history taking. \\
\hline 3.2 & Laboratory method & Sxample: joint mobility assessment \\
\hline 3.3 & Diagnostic technique & Treatment methods for studying disease elements. Example: ultrasound imaging of the joint \\
\hline 3.4 & Medical consultation & Active substances for gout treatment. Example: allopurinol \\
\hline 4 & Therapy & Methods of non-pharmacological treatment of gout. Example: Diet № 6 \\
\hline 4.1 & Active substance & \\
\hline 4.2 & Non-pharmacological therapy & \\
\hline
\end{tabular}


Table 3. Number of diagnostic algorithms for gout; functional classification of joint damage is not included

\begin{tabular}{|c|l|c|c|}
\hline № & \multicolumn{1}{|c|}{$\begin{array}{c}\text { "Diagnosis } \\
\text { (functional class of joint damage not included)" }\end{array}$} & Number of algorithms without FC & Number of algorithms with FC \\
\hline 1 & Acute gouty arthritis & 2 & 8 \\
\hline 2 & Intercritical gout & 1 & 4 \\
\hline 3 & Acute intermittent gout. Acute gouty arthritis & 2 & 8 \\
\hline 4 & Chronic tophaceous gout. Chronic gouty arthritis, intercritical phase & 3 & 12 \\
\hline 5 & Chronic tophaceous gout. Chronic gouty arthritis, acute phase & 2 & 8 \\
\hline & Total & 10 & 40 \\
\hline
\end{tabular}

should also be accounted for when developing rules for a clinical decision support system.

\section{Polarized light microscopy of synovial fluid}

According to clinical guidelines, the findings of polarized light microscopy of synovial fluid should be described in terms of 1) presence of monosodium urate crystals in synovial fluid (8 points), 2) absence of monosodium urate crystals in synovial fluid (-2 points) and 3) no test results available (0 points).

Importantly, it is not the binary choice (the presence or absence of a symptom) that should be implemented in a clinical decision support system, but the choice between 3 states: the presence of a symptom, its absence or no data available.

The algorithms, their scores and the logic for score calculation needed for further ontology building were described in MS Excel. Symptoms that could be expressed numerically were represented as a range of possible values and units of measurement consistent with the information in the Units of Measurements reference book [21].

The designed diagnostic algorithms were approved by the expert panel using the comparison method. The experts confirmed that the algorithms were verified and could be used for ontology building.

\section{Algorithms for gout treatment}

The process of developing algorithms for gout treatment differed from the process of developing diagnostic algorithms. Treatment algorithms were broken down into the following steps: 1) selecting a general therapeutic strategy; 2) selecting an optimal pharmaceutical substance(s); 3) determining hospitalization criteria.

To provide a clear description of the therapeutic strategy, the panel of experts working in collaboration with the authors of this paper proposed a logical model that comprised 50 different scenarios of treating a gout attack. The algorithms were visualized in MS Visio (Fig. 1), which enabled us to discuss every scenario without going into technicalities. The following steps are included in each scenario:

1) a drug category is chosen (a specific drug will be proposed in the next step); the choice is made between colchicine, NSAIDs, proton pump inhibitors, glucocorticoids, canakinumab, and the combination of these drugs. Due to the specifics of glucocorticoid therapy, glucocorticoid entries are annotated with information about the route of administration (intra-articular, intramuscular, oral);

2) the timeline for medical consultations is specified; consultations are seen as transition points between different treatment scenarios and hospitalization;

3) criteria are set for scenario selection and switching between different scenarios.

Scenarios for gout attack prevention (small doses of colchicine, NSAIDs, glucocorticoids) and serum urate lowering (allopurinol, febuxostat) should be analyzed separately.

In the second step, one or several active pharmaceutical substances are selected as a possible treatment option. These substances will be recommended later, in the form of a regimen that accounts for the drug dose, dosing frequency, route of administration, etc. Each active substance is annotated with a list of contraindications so that dangerous prescriptions could be avoided.

Treatment algorithms were described in MS Excel (Fig. 2). The resultant table contains information returned to the user by the system if the specified criteria are met.

The following rules and limitations were introduced during the development of treatment algorithms for gout patients:

1. Priority should be given to a higher-ranked drug, i.e. the system will recommend the drug if prescription criteria are met and no contraindications are detected.

2. If none of the drugs (active substances) can be prioritized or prescription criteria for these drugs are different, the drugs should be grouped together (see the Group number box in Fig. 2).

3. If several active substances are prescribed, this information will be visually presented to the user as shown in Fig. 3. Example: a combination therapy of one NSAID and one $\mathrm{PPI}$ is recommended. Priority is set according to the specified criteria but information is presented to the user in separate blocks.

Thus, the entire process of treatment can have a structured formal representation; at the same time, the rules underlying decision making are available to the user and can be analyzed.

The proposed treatment algorithms were compared, verified and recommended for further ontology building by the panel of experts.

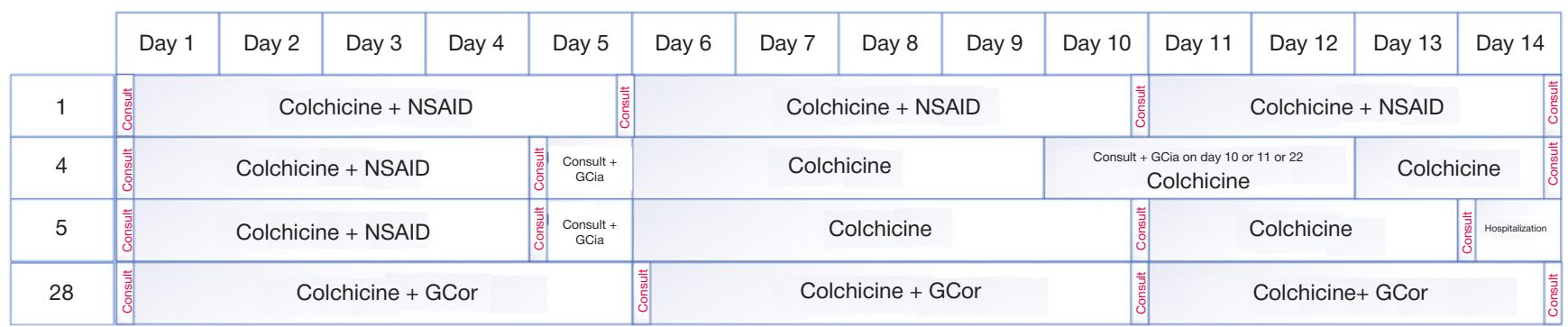

Fig. 1. Visual representation of a teratment scenario. GCia — intra-articular glucocorticoid, GCor — oral glucocorticoid 


\begin{tabular}{|c|l|c|c|c|c|c|c|c|}
\hline & Active substance & Dose & $\begin{array}{c}\text { Unit of } \\
\text { measurement }\end{array}$ & Dosing frequency & $\begin{array}{c}\text { Unit of measurement for dosing } \\
\text { frequency }\end{array}$ & Therapy duration & Unit of time & $\begin{array}{c}\text { Route of } \\
\text { administration }\end{array}$ \\
\hline 1 & Naproxen & 275 & $\mathrm{mg}$ & 3 & Once a day & 8 & Day & Oral \\
\hline 2 & Nimesulide & 100 & $\mathrm{mg}$ & 2 & Once a day & 8 & Day & Oral \\
\hline 3 & Diclofenac & 50 & $\mathrm{mg}$ & 3 & Once a day & 8 & Day & Oral \\
\hline 4 & Etoricoxib & 120 & $\mathrm{mg}$ & 1 & Once a day & 8 & Day & Oral \\
\hline 5 & Naproxen & 550 & $\mathrm{mg}$ & 2 & Once a day & 8 & Day & Oral \\
\hline 6 & Nimesulide & 100 & $\mathrm{mg}$ & 2 & Once a day & 8 & Day & Oral \\
\hline 7 & Diclofenac & 50 & $\mathrm{mg}$ & 3 & Once a day & 8 & Day & Oral \\
\hline 8 & Etoricoxib & 120 & $\mathrm{mg}$ & 1 & Once a day & 8 & Day & Oral \\
\hline 9 & Celecoxib & 400 & $\mathrm{mg}$ & 1 & Once a day & 8 & Day & Oral \\
\hline 10 & Aceclofenac & 200 & $\mathrm{mg}$ & 1 & Once a day & 8 & Day & Oral \\
\hline 11 & Tenoxicam & 20 & $\mathrm{mg}$ & 3 & Once a day & 8 & Day & Intramuscular \\
\hline 12 & Ketoprofen & 100 & $\mathrm{mg}$ & 2 & Once a day & 8 & Day & Intramuscular \\
\hline 13 & Dexketoprofen & 25 & $\mathrm{mg}$ & 3 & Once a day & 8 & Day & Oral \\
\hline 14 & Dexketoprofen & 50 & $\mathrm{mg}$ & 3 & Once a day & 8 & Day & Intravenous \\
\hline 15 & Indomethacin & 25 & $\mathrm{mg}$ & 3 & Once a day & 8 & Day & Oral \\
\hline 16 & Ibuprofen & 400 & $\mathrm{mg}$ & 3 & Once a day & 8 & Day & Oral \\
\hline 17 & Piroxicam & 20 & $\mathrm{mg}$ & 1 & Once a day & 8 & Day & Oral \\
\hline 18 & Lornoxicam & 8 & $\mathrm{mg}$ & 2 & Once a day & 8 & Day & Oral \\
\hline 19 & Etodolac & 400 & $\mathrm{mg}$ & 3 & Once a day & 8 & Day & Oral \\
\hline
\end{tabular}

\begin{tabular}{|c|c|c|c|c|c|c|c|c|}
\hline & Active substance & Dose & $\begin{array}{l}\text { Unit of } \\
\text { measurement }\end{array}$ & Dosage form & $\begin{array}{l}\text { Timing with } \\
\text { meals }\end{array}$ & Prescription criteria & $\begin{array}{c}\text { Special } \\
\text { notes }\end{array}$ & $\begin{array}{c}\text { Group } \\
\text { number }\end{array}$ \\
\hline 1 & Naproxen & 275 & $\mathrm{mg}$ & Tablets & $\begin{array}{l}\text { Irrespective of } \\
\text { meals }\end{array}$ & $\begin{array}{l}\text { Age ( }>65 \text { years); Colchicine; Duration of acute } \\
\text { gouty arthritis ( }>3 \text { days) }\end{array}$ & & 1 \\
\hline 2 & Nimesulide & 100 & $\mathrm{mg}$ & Tablets & $\begin{array}{l}\text { Irrespective of } \\
\text { meals }\end{array}$ & $\begin{array}{l}\text { Age (>65 years); Colchicine; Duration of acute } \\
\text { gouty arthritis ( }>3 \text { days) }\end{array}$ & & 1 \\
\hline 3 & Diclofenac & 50 & $\mathrm{mg}$ & Tablets & $\begin{array}{l}\text { Irrespective of } \\
\text { meals }\end{array}$ & $\begin{array}{l}\text { Age (>65 years); Colchicine; Duration of acute } \\
\text { gouty arthritis ( }>3 \text { days) }\end{array}$ & & 1 \\
\hline 4 & Etoricoxib & 120 & $\mathrm{mg}$ & Tablets & $\begin{array}{l}\text { Irrespective of } \\
\text { meals }\end{array}$ & $\begin{array}{l}\text { Age (>65 years); Colchicine; Duration of acute } \\
\text { gouty arthritis ( }>3 \text { days) }\end{array}$ & & 1 \\
\hline 5 & Naproxen & 550 & $\mathrm{mg}$ & Tablets & $\begin{array}{l}\text { Irrespective of } \\
\text { meals }\end{array}$ & $\begin{array}{l}\text { Colchicine; Duration of acute gouty arthritis } \\
\qquad(>3 \text { days) }\end{array}$ & & 2 \\
\hline 6 & Nimesulide & 100 & $\mathrm{mg}$ & Tablets & $\begin{array}{l}\text { Irrespective of } \\
\text { meals }\end{array}$ & $\begin{array}{l}\text { Colchicine; Duration of acute gouty arthritis } \\
\text { ( }>3 \text { days) }\end{array}$ & & 2 \\
\hline 7 & Diclofenac & 50 & $\mathrm{mg}$ & Tablets & $\begin{array}{l}\text { Irrespective of } \\
\text { meals }\end{array}$ & $\begin{array}{c}\text { Colchicine; Duration of acute gouty arthritis } \\
(>3 \text { days })\end{array}$ & & 2 \\
\hline 8 & Etoricoxib & 120 & $\mathrm{mg}$ & Tablets & $\begin{array}{l}\text { Irrespective of } \\
\text { meals }\end{array}$ & $\begin{array}{l}\text { Colchicine; Duration of acute gouty arthritis } \\
\text { ( }>3 \text { days) }\end{array}$ & & 2 \\
\hline 9 & Celecoxib & 400 & $\mathrm{mg}$ & Capsules & $\begin{array}{l}\text { Irrespective of } \\
\text { meals }\end{array}$ & $\begin{array}{l}\text { Colchicine; Duration of acute gouty arthritis } \\
\qquad>3 \text { days })\end{array}$ & & 3 \\
\hline 10 & Aceclofenac & 200 & $\mathrm{mg}$ & Prolonged-release tablets & With meals & $\begin{array}{l}\text { Colchicine; Duration of acute gouty arthritis } \\
\qquad>3 \text { days) }\end{array}$ & & 3 \\
\hline 11 & Tenoxicam & 20 & $\mathrm{mg}$ & $\begin{array}{l}\text { For injection, lyophilized } \\
\text { powder for } \\
\text { intramuscular use }\end{array}$ & $\begin{array}{l}\text { Irrespective of } \\
\text { meals }\end{array}$ & $\begin{array}{l}\text { Colchicine; Duration of acute gouty arthritis } \\
\qquad(>3 \text { days) }\end{array}$ & & 4 \\
\hline 12 & Ketoprofen & 100 & $\mathrm{mg}$ & $\begin{array}{l}\text { For injection, for } \\
\text { intramuscular use }\end{array}$ & $\begin{array}{l}\text { Irrespective of } \\
\text { meals }\end{array}$ & $\begin{array}{l}\text { Colchicine; Duration of acute gouty arthritis } \\
\text { ( }>3 \text { days) }\end{array}$ & & 4 \\
\hline 13 & Dexketoprofen & 25 & $\mathrm{mg}$ & Granules, for solution & $\begin{array}{l}\text { Irrespective of } \\
\text { meals }\end{array}$ & $\begin{array}{c}\text { Colchicine; Duration of acute gouty arthritis } \\
\text { ( }>3 \text { days })\end{array}$ & & 4 \\
\hline 14 & Dexketoprofen & 50 & $\mathrm{mg}$ & $\begin{array}{l}\text { For injection, for } \\
\text { intravenous use }\end{array}$ & $\begin{array}{l}\text { Irrespective of } \\
\text { meals }\end{array}$ & $\begin{array}{l}\text { Colchicine; Duration of acute gouty arthritis } \\
\qquad(>3 \text { days })\end{array}$ & & 4 \\
\hline 15 & Indomethacin & 25 & $\mathrm{mg}$ & Tablets & $\begin{array}{l}\text { Irrespective of } \\
\text { meals }\end{array}$ & $\begin{array}{c}\text { Colchicine; Duration of acute gouty arthritis } \\
\text { ( }>3 \text { days) }\end{array}$ & & 4 \\
\hline 16 & Ibuprofen & 400 & $\mathrm{mg}$ & Tablets & With meals & $\begin{array}{l}\text { Colchicine; Duration of acute gouty arthritis } \\
\qquad(>3 \text { days) }\end{array}$ & & 4 \\
\hline 17 & Piroxicam & 20 & $\mathrm{mg}$ & Tablets & With meals & $\begin{array}{l}\text { Colchicine; Duration of acute gouty arthritis } \\
\text { ( }>3 \text { days) }\end{array}$ & & 4 \\
\hline 18 & Lornoxicam & 8 & $\mathrm{mg}$ & Tablets & $\begin{array}{l}\text { Irrespective of } \\
\text { meals }\end{array}$ & $\begin{array}{l}\text { Colchicine; Duration of acute gouty arthritis } \\
\text { ( }>3 \text { days) }\end{array}$ & & 4 \\
\hline 19 & Etodolac & 400 & $\mathrm{mg}$ & Tablets & $\begin{array}{l}\text { Irrespective of } \\
\text { meals }\end{array}$ & $\begin{array}{l}\text { Colchicine; Duration of acute gouty arthritis } \\
\qquad(>3 \text { days) }\end{array}$ & & 4 \\
\hline
\end{tabular}

Fig. 2. An example of treatment algorithm (a nonsteroidal anti-inflammatory drug) 


\begin{tabular}{|c|c|c|c|c|c|}
\hline \multirow{10}{*}{$\begin{array}{l}\text { Combination therapy with nonsteroidal anti-inflammatory } \\
\text { drugs and proton pump inhibitors is recommended }\end{array}$} & & & Active substance & One-time dose & Unit of measurement for single dose \\
\hline & \multirow{3}{*}{$\begin{array}{l}\text { Nonsteroidal } \\
\text { anti-inflammatory drugs }\end{array}$} & 1 & Celecoxib & 400 & $\mathrm{mg}$ \\
\hline & & 2 & Etoricoxib & 120 & $\mathrm{mg}$ \\
\hline & & 3 & Nimesulide & 100 & $\mathrm{mg}$ \\
\hline & \multirow{6}{*}{ Proton pump inhibitors } & 1 & Pantoprazole & 40 & $\mathrm{mg}$ \\
\hline & & 2 & Omeprazole & 20 & $\mathrm{mg}$ \\
\hline & & 3 & Rabeprazole & 20 & $\mathrm{mg}$ \\
\hline & & 4 & Esomeprazole & 40 & $\mathrm{mg}$ \\
\hline & & 5 & Dexlansoprazole & 30 & $\mathrm{mg}$ \\
\hline & & 6 & Lansoprazole & 15 & $\mathrm{mg}$ \\
\hline
\end{tabular}

Fig. 3. Visual representation of combination therapy with active substances

\section{DISCUSSION}

The proposed verified nomenclature of medical entities pertaining to the diagnosis and treatment of gout has laid the foundation for the future ontology. The rigorous classification scheme and the generalization of entities suggest that the conceptual model, which is currently in development, has a specification: each entity included in the model has an explicitly described role. Categorizing the entities into the groups of main terms and their synonyms is important for ontology building because it allows using terminologies from different schools of medical thought and expanding the existing list of terms. Thus, the principle of a shared conceptual model is implemented. Because clinical diagnoses had unambiguous definitions, we were able to proceed to the development of treatment algorithms for gout patients.

The proposed verified diagnostic algorithms will be later used to build the diagnostic domain of the future ontology. The identified patterns (diagnostic stages, specific work of logic with individual entities (or their groups) that contribute to the diagnosis of gout, the need to use 3 states for some entities that explicitly affect the diagnosis) will underpin the structure of the future ontology, help to fill it with data and be used to elaborate algorithms for the expert system. Unambiguous definition of units of measurement for all quantitative symptoms also suggest that our conceptual model has a specification.

The proposed verified treatment algorithms will be used to build the treatment domain of the future ontology, fill it with data and develop an expert system for the optimization of gout treatment regimens and patient monitoring.

The algorithms proposed in this paper are described in MS Excel. This means that the accumulated knowledge now has a formal representation and can be transferred to an ontology by means of special software tools. On the other hand, MS Excel tools can be used by experts to further expand the ontology.

We were unable to compare our medical nomenclature of gout-related terms with similar informational objects because currently existing expert systems either are based on a different approach [22] or do not provide data for comparison [23]. On the other hand, there is a wealth of studies that utilize similar methods of knowledge extraction, structuring and formalization but pertain to other medical fields, like angina pectoris [24], intestinal bleeding [25], etc. However, it is impossible to objectively compare the results of those studies with the results of our work.

\section{CONCLUSIONS}

We have developed a medical nomenclature of terms pertaining to the diagnosis and treatment of gout using literature sources and expert opinions. The diagnostic domain includes 179 main terms and 470 synonyms, whereas the treatment domain comprises 387 main terms and 515 synonyms. We have also designed formal diagnostic and treatment algorithms for gout patients (40 and 50 scenarios, respectively) that will be instrumental in building a clinical decision support system suitable for use in an outpatient setting.

\section{References}

1. Ministerstvo zdravoohranenija Rossii. Podagra. Klinicheskie rekomendacii. 2018. Dostupno po ssylke: http://www.ma.cfuv.ru/ docs/249620/\%D0\%9A\%D0\%A0\%20\%D0\%9F\%D0\%BE\%D0\% B4\%D0\%B0\%D0\%B3\%D1\%80\%D0\%B0.pdf. Russian.

2. Vorobev PA, Curko W, Eliseeva ME. Podagra $\vee$ geriatricheskoj praktike. Klinicheskaja gerontologija. 2016; 22 (3-4). Russian.

3. Karnakova MV, Kalyagin AN. Izmenilos' li klinicheskoe techenie podagry v poslednee vremja? Sovremennaja revmatologija. 2017; 11 (1): 23-27. Russian.

4. Kirillova YeR. Vozmozhnosti ul'trazvukovogo issledovanija v diagnostike podagry. Prakticheskaja medicina. 2018; 16 (7): 1178. Russian.

5. Eliseev MS. Klassifikacionnye kriterii podagry (rekomendacii ACR/ EULAR). Nauchno-prakticheskaja revmatologija. 2015; 53 (6): 581-5. Russian.

6. Prikaz Ministerstva zdravoohranenija i social'nogo razvitija RF ot 15.05.2012 № 543n «Ob utverzhdenii Polozhenija ob organizacii okazanija pervichnoj mediko-sanitarnoj pomoshhi vzroslomu

naseleniju» (red. 21 fevralja 2020 g.). Dostupno po ssylke: https:// base.garant.ru/70195856/. Russian.

7. Rugol LV, Son IM, Menshikova LI. Vlijanie kadrovogo obespechenija pervichnoj mediko-sanitarnoj pomoshhi na jeffektivnost' ee dejatel'nosti. Social'nye aspekty zdorov'ja naselenija. 2020; 66 (3): 9. Russian.

8. Son IM, Ivanova MA, Sokolovskaya TA, Lyucko W, Dezhurny LI. Dejatel'nost' i obespechennost' vrachami-revmatologami v Rossijskoj Federacii, 2013-2017 g. Kardiovaskuljarnaja terapija i profilaktika. 2019; 18 (1): 134-42. Russian.

9. Barskova VG, Eliseev MS, Vladimirov SA. Diagnostika mikrokristallicheskoj patologii sustavov metodom poljarizacionnoj mikroskopii (traktovka i metodicheskie rekomendacii $k$ issledovaniju). Sovremennaja revmatologija. 2010; (1): 84-88. Russian.

10. Zhuravlyova LV, Fyodorov VA. Podagra: trudnosti i oshibk svoevremennoj diagnostiki. Praktikujuchij likar. 2019; 3: 32-38. Russian.

11. Frolov SV, Kulikov AYu, Ostapenko OA, Strygina EV. Sistemy podderzhki vrachebnyh reshenij $\vee$ medicine. Nauchnyj zhurnal. 
2018; 9 (32). Russian.

12. Gavrilova TA, Kudryavcev DV, Muromcev DI. Inzhenerija znanij. Modeli i metody. M.: Lan', 2020; 324 s. Russian.

13. Gavrilova TA, Horoshevskij VF. Bazy Znanij Intellektual'nyh Sistem. SPb.: Piter, 2000; 384 s. Russian.

14. Berner ES, editor. Clinical Decision Support Systems. New York: Springer, 2007; $270 \mathrm{p}$.

15. Wagholikar KB, Sundararajan V, Deshpande AW. Modeling paradigms for medical diagnostic decision support: A survey and future directions. J Med Syst. 2012; 36 (5): 3029-49. DOI: 10.1007/s10916-011-9780-4

16. Gribova V, Kleshhev AS, Moskalenko FM, Timchenko VA Fedorishhev LA, Shalfeeva EA. Oblachnaja platforma IACPaaS: tekushhee sostojanie i perspektivy razvitija. Informacionnye I matematicheskie tehnologii v nauke i upravlenii. 2016; 2: 94-100. Russian.

17. Gribova W, Petraeva MV, Okun DB, Shalfeeva EA. Ontologija medicinskoj diagnostiki dlja intellektual'nyh sistem podderzhki prinjatija reshenij. Ontol Des. 2018; 8 (1): 58-73. DOl: 10.18287/2223-9537-2018-8-1-58-73. Russian.

18. Gosudarstvennyj reestr lekarstvennyh sredstv. Dostupno po ssylke: https://grls.rosminzdrav.ru/grls.aspx. Russian.

19. Ministerstvo zdravoohranenija Rossijskoj Federacii. Associacija vrachej obshhej praktiki (semejnyh vrachej) Rossijskoj Federacii.
Klinicheskie rekomendacii dlja vrachej obshhej praktiki (semejnyh vrachej). Podagra. 2015. Dostupno po ssylke: https:// endouroclinic.ru/media/file-galleries/apbowb/Podagra\%20 Rukovodstvo\%202015.PDF. Russian.

20. Shostak NA, Pravdjuk NG, Klimenko AA, Kondrashov AA. Bolevoj sindrom v revmatologii. Medicinskij sovet. 2013; 12: 113-7. Russian.

21. Edinicy izmerenija. Dostupno po ssylke: https://nsi.rosminzdrav. ru/\#!/refbook/1.2.643.5.1.13.13.11.1358. Russian.

22. Qwaider SR, Abu Naser SS. Expert System for Diagnosing Ankle Diseases. Int J Eng Inf Syst. 2017; 1 (4): 89-101.

23. Zheng $\mathrm{C}$, Rashid N, Wu YL, et al. Using Natural Language Processing and Machine Learning to Identify Gout Flares From Electronic Clinical Notes. Arthritis Care Res. 2014; 66 (11): 17408. DOI: $10.1002 / a c r .22324$

24. Kiselev KV, Potehina AV, Osjaeva MK, i dr. Razrabotka nomenklatury ponjatij dlja sistemy podderzhki prinjatija vrachebnyh reshenij v oblasti diagnostiki stenokardii I-IV funkcional'nyh klassov. Evrazijskij kardiologicheskij zhurnal. 2018; 3: 14-19. Russian.

25. Budykina AV, Kiselev KV, Rauzina SE, et al. Ontologija diagnostiki i lechenija zheludochno-kishechnyh krovotechenij s neustanovlennym istochnikom. V sbornike: Znanija-OntologiiTeorii (ZONT-2019). Materialy XII mezhdunarodnoj konferencii; Novosibirsk, 07-11 oktjabrja 2019 goda. Institut matematiki im. S.L. Soboleva SO RAN, 2019; s. 88-93. Russian.

\section{Литература}

1. Министерство здравоохранения России. Подагра. Клинические рекомендации. 2018. Доступно по ссылке: http://www. ma.cfuv.ru/docs/249620/\%D0\%9A\%D0\%A0\%20\%D0\%9F\%D0 \%BE\%D0\%B4\%D0\%B0\%D0\%B3\%D1\%80\%D0\%B0.pdf.

2. Воробьев П. А., Цурко В. В., Елисеева М. Е. Подагра в гериатрической практике. Клиническая геронтология. 2016; $22(3-4)$.

3. Карнакова М. В., Калягин А. Н. Изменилось ли клиническое течение подагры в последнее время? Современная ревматология. 2017; 11 (1): 23-27.

4. Кириллова Э. Р. Возможности ультразвукового исследования в диагностике подагры. Практическая медицина. 2018; 16 (7): 117-8.

5. Елисеев М. С. Классисикационные критерии подагры (рекомендации ACR/EULAR). Научно-практическая ревматология. 2015; 53 (6): 581-5.

6. Приказ Министерства здравоохранения и социального развития РФ от 15.05.2012 № 543н «Об утверждении Положения об организации оказания первичной медикосанитарной помощи взрослому населению» (ред. 21 февраля 2020 г.). Доступно по ссылке: https://base.garant.ru/70195856/.

7. Руголь Л. В., Сон И. М., Меньшикова Л. И. Влияние кадрового обеспечения первичной медико-санитарной помощи на эффективность ее деятельности. Социальные аспекть здоровья населения. 2020; 66 (3): 9.

8. Сон И. М., Иванова М. А., Соколовская Т. А., Люцко В. В. Дежурный Л. И. Деятельность и обеспеченность врачамиревматологами в Российской Федерации, 2013-2017 г. Кардиоваскулярная терапия и просрилактика. 2019; 18 (1): 134-42.

9. Барскова В. Г., Елисеев М. С., Владимиров С. А. Диагностика микрокристаллической патологии суставов методом поляризационной микроскопии (трактовка и методические рекомендации к исследованию). Современная ревматология. 2010; (1): 84-88.

10. Журавлёва Л. В., Фёдоров В. А. Подагра: трудности и ошибки своевременной диагностики. Практикуючий лікар. 2019; 3: 32-38.

11. Фролов С. В., Куликов А. Ю., Остапенко О. А., Стрыгина Е. В. Системы поддержки врачебных решений в медицине. Научный журнал. 2018; 9 (32).

12. Гаврилова Т. А., Кудрявцев Д. В., Муромцев Д. И. Инженерия знаний. Модели и методы. М.: Лань, 2020; 324 с.

13. Гаврилова Т. А., Хорошевский В. Ф. Базы Знаний Интеллектуальных Систем. СПб.: Питер, 2000; 384 с.

14. Berner ES, editor. Clinical Decision Support Systems. New York: Springer, 2007; $270 \mathrm{p}$.

15. Wagholikar KB, Sundararajan V, Deshpande AW. Modeling paradigms for medical diagnostic decision support: A survey and future directions. J Med Syst. 2012; 36 (5): 3029-49. DOI: 10.1007/s10916-011-9780-4.

16. Грибова В. В., Клещев А. С., Москаленко Ф. М., Тимченко В. А., Федорищев Л. А., Шалфеева Е. А. Облачная платформа IACPaaS: текущее состояние и перспективы развития. Информационные и математические технологии в науке и управлении. 2016; 2: 94-100.

17. Грибова В. В., Петряева М. В., Окунь Д. Б., Шалфеева Е. А. Онтология медицинской диагностики для интеллектуальных систем поддержки принятия решений. Ontol Des. 2018; 8 (1): 58-73. DOI: 10.18287/2223-9537-2018-8-1-58-73

18. Государственный реестр лекарственных средств. Доступно по ссылке: https://grls.rosminzdrav.ru/grls.aspx

19. Министерство здравоохранения Российской Федерации. Ассоциация врачей общей практики (семейных врачей) Российской Федерации. Клинические рекомендации для врачей общей практики (семейных врачей). Подагра. 2015. Доступно по ссылке: https://endouroclinic.ru/media/filegalleries/qpbowb/Podagra\%20Rukovodstvo\%202015.PDF.

20. Шостак Н. А., Правдюк Н. Г., Клименко А. А., Кондрашов А. А. Болевой синдром в ревматологии. Медицинский совет. 2013; 12: $113-7$.

21. Единицы измерения. Доступно по ссылке: https://nsi. rosminzdrav.ru/\#!/refbook/1.2.643.5.1.13.13.11.1358.

22. Qwaider SR, Abu Naser SS. Expert System for Diagnosing Ankle Diseases. Int J Eng Inf Syst. 2017; 1 (4): 89-101.

23. Zheng $\mathrm{C}$, Rashid $\mathrm{N}, \mathrm{Wu} \mathrm{YL}$, et al. Using Natural Language Processing and Machine Learning to Identify Gout Flares From Electronic Clinical Notes. Arthritis Care Res. 2014; 66 (11): 17408. DOI: 10.1002/acr.22324.

24. Киселев К. В., Потехина А. В., Осяева М. К., и др. Разработка номенклатуры понятий для системы поддержки принятия врачебных решений в области диагностики стенокардии I-IV функциональных классов. Евразийский кардиологический журнал. 2018; 3: 14-19.

25. Будыкина А. В., Киселев К. В., Раузина С. Е., et al. Онтология диагностики и лечения желудочно-кишечных кровотечений с неустановленным источником. В сборнике: Знания-Онтологии-Теории (ЗОНТ-2019). Материалы XII международной конференции; Новосибирск, 07-11 октября 2019 года. Институт математики им. С.Л. Соболева СО РАН, 2019; с. 88-93. 